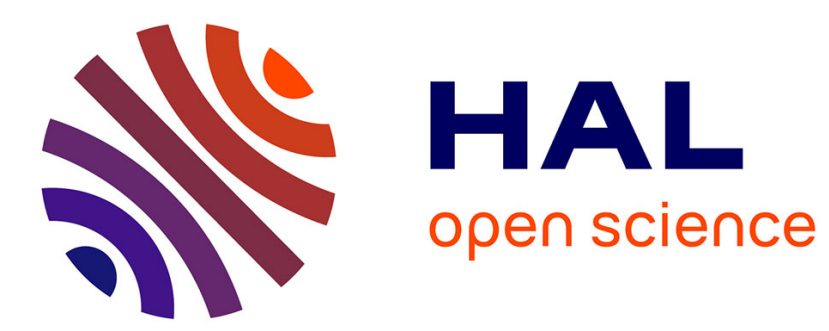

\title{
WELDING OF CERAMICS SiO2-Al2O3 BY LASER BEAM
}

\author{
A. de Paris, M. Robin, Gilbert Fantozzi
}

\section{To cite this version:}

A. de Paris, M. Robin, Gilbert Fantozzi. WELDING OF CERAMICS SiO2-Al2O3 BY LASER BEAM. Journal de Physique IV Proceedings, 1991, 01 (C7), pp.C7-127-C7-129. 10.1051/jp4:1991726 . jpa00250929

\section{HAL Id: jpa-00250929 https://hal.science/jpa-00250929}

Submitted on 1 Jan 1991

HAL is a multi-disciplinary open access archive for the deposit and dissemination of scientific research documents, whether they are published or not. The documents may come from teaching and research institutions in France or abroad, or from public or private research centers.
L'archive ouverte pluridisciplinaire HAL, est destinée au dépôt et à la diffusion de documents scientifiques de niveau recherche, publiés ou non, émanant des établissements d'enseignement et de recherche français ou étrangers, des laboratoires publics ou privés. 


\title{
WELDING OF CERAMICS $\mathrm{SiO}_{2}-\mathrm{Al}_{2} \mathrm{O}_{3}$ BY LASER BEAM
}

\author{
A. de PARIS, M. ROBIN and G. FANTOZZI \\ GEMPPM-CALFETMAT (CNRS UA-341), INSA-LYON, Bât. 403, F-69621 Villeurbanne cedex, France
}

\begin{abstract}
A} \mathrm{CO} 2$ laser beam was used for welding $\mathrm{SiO}_{2}-\mathrm{Al}_{2} \mathrm{O}_{3}$ ceramic tubes with $60 \mathrm{wt} \%$ alumina content. To prevent weld cracking a preheating process with radiant energy produced by halogen lamps and collected by reflectors was used. Several evaluation techniques like helium checking, Vickers indentation and flexural resistance were employed to study weldzone characteristics.
\end{abstract}

\section{1.- Introduction}

In the last years the development of technical ceramics has been strongly intensified. Their use is desirable amongst other reasons due to their excellent high temperature strength, their resistance to corrosion and their high resistance to wear. Because of their weak points such as difficult processing and small resistance to thermal shock, application of ceramics has been practically restricted. Methods for processing complicated shape parts and products as well as use of ceramics in severe environnement will make a new mark in expanding advanced ceramic application [1]. One of such processing methods is ceramic joining. Amongst the joining techniques (cement, brazing; etc...), the utilization of a laser beam shows helpful for welding oxides ceramics.

\section{2.- Experimental procedure}

As the weld specimens, tubes $\varnothing 8 \times 5 \mathrm{~mm}$ of $\mathrm{SiO}_{2}-\mathrm{Al}_{2} \mathrm{O}_{3}$ ceramics with $60 \mathrm{wt} \%$ alumina were used. As a laser equipment a $\mathrm{CO}_{2}$ source is used because its wave length of about $10,6 \mu \mathrm{m}$ is more highly absorbed by ceramics than by metals. One of the major problems in the fusion welding of ceramic materials is the control of cracking caused by thermal stresses. If a section of ceramic material is melted, a very high temperature gradient is set up in the adjacent unmelted material, with proportionally high thermal stresses [2]. The solution has been to provide supplementary heating in a broader zone around the weld area so that the net thermal gradient of the supplementary heating and the welding source is now sufficiently low so that no thermal stresses high enough to cause cracking are reached. This supplementary heating also allows the part to be heated and cooled slowly enough to avoid thermal shock. In order to prevent weld cracking, ceramic specimens were preheated with radiant energy produced by halogen lamps and collected by reflectors.

\section{3.- Results and discussion}

Except for provisions for preheating during the ceramic welding, the welding process was essentially the same as that used for metal welding. Welding techniques were established by an investigation of the effects of the processing parameters on weld characteristics. One problem found 
when welding $\mathrm{SiO}_{2}-\mathrm{Al}_{2} \mathrm{O}_{3}$ ceramic material is the porosity. Since ceramic material is porous, porosity tend to be produced in the weld bead. A lot of round small porosities which are not connected each other were found along fusion boundary. These pores are considered to be coalescence of porosities of the parent material [3] or residual vapors which are due to silica vaporization at high temperature [4]. During welding there are motions in the weld pool due the surface tension gradient. Surface tension gradients exist on a weld pool surface, because the surface tension is temperature dependent and there are substantial temperatures gradients on a weld pool surface [5]. This motion project the porosities in direction of the weld interface and they remain imprisoned, figure 1.

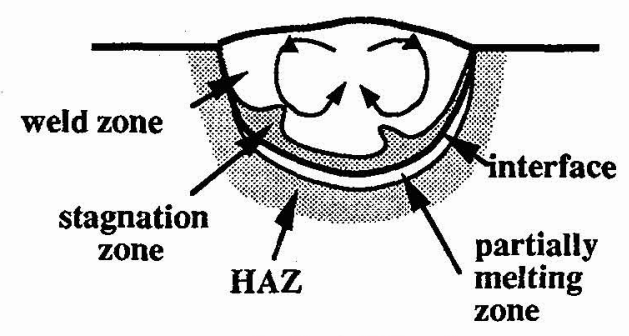

a) $d y / d T<0$

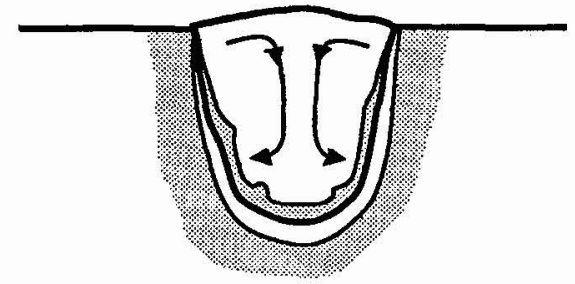

b) $\mathrm{d} \gamma / \mathrm{d} \mathbf{T}>\mathbf{0}$

Fig. 1 - Motion of the molten pool. The convection flowing sense is function of the factor $d \gamma / d T$.

The high viscosity due to a comparatively lower temperature near fusion boundary prevents the bubbles in the melt from going to the surface during welding. Figure 2 shows the microstructure of the ceramic specimens: an amorphous glass phase with mullite crystal like needle and alumina crystals. Figure 3 shows an example of cross-section of the weld bead observed with an optical microscope. Crystals of mullite $3 \mathrm{Al}_{2} \mathrm{O}_{3} .2 \mathrm{SiO}_{2}$ and an amorphous silica phase.

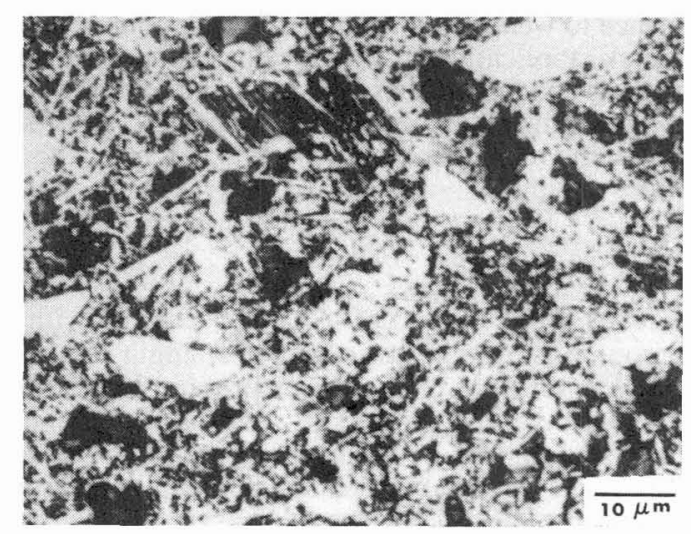

Fig. 2 - Microstructure of parent material, mullite like needles in an amorphous silica (black) with crystals of alumina (grey).

The study of the relationships between welding parameters and weld-zone characteristics was supported by several evaluation techniques. Determination of cracking was based on visual examination at high magnifications. No cracking was found. Hermeticity of the joints was confirmed by helium leak checking. Flexural bend testing of welded ceramcis indicated that good joint strengths can be obtained. Under simple beam bending the base ceramic achieved a surface stress of approximately $\sigma_{\mathrm{f}}=125 \mathrm{MPa}$. Laser beam welded joints withstood $\sigma_{\mathrm{f}}=125 \mathrm{MPa}$, the fracture begins on the substrate ceramic and propagates to the welding bead, figure 4 . Vickers indentation technique was used for measuring the hardness at room temperature. The weld exhibits an increase in hardness of about $50 \%$ with regard to parent material due to both microstructural and densification changes, figure 5 . 

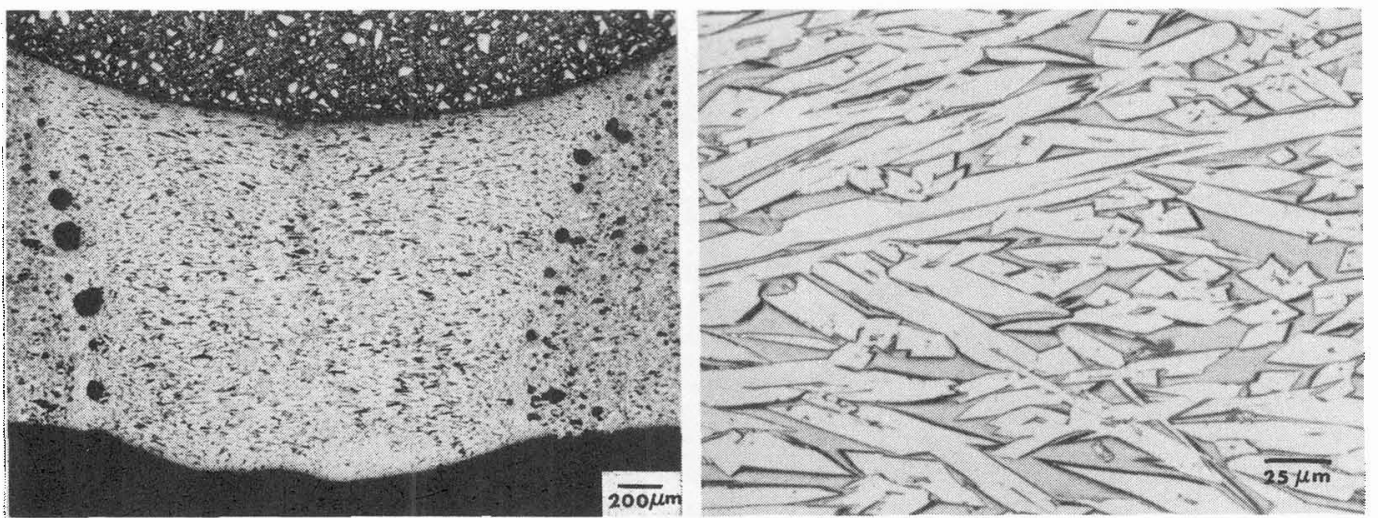

Fig. 3 - (a) Cross-section of a weld bead with porosities at interface, (b) microstructure of the weld bead, mullite needles in an amorphous silica glass.

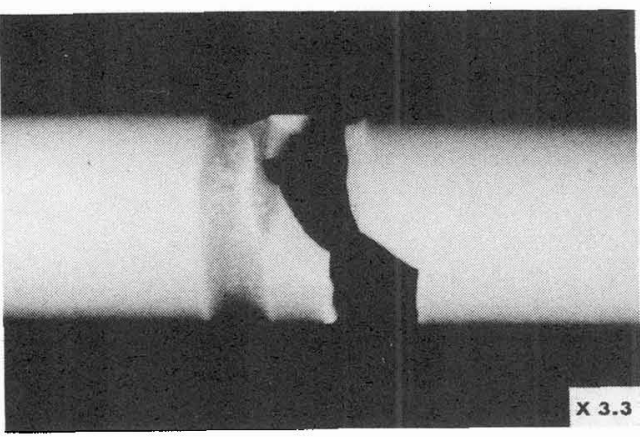

Fig. 4 - Broken specimen by 4-point bend test. Fracture starts on the parent material and propagates to the weld bead.

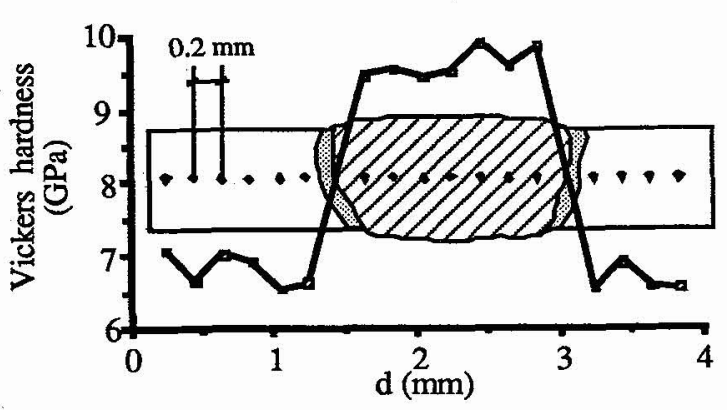

Fig. 5 - Vickers indentation. The hardness of the weld bead increase about $50 \%$ with regard to base ceramic.

\section{4.- Conclusion}

The possibility of welding ceramics using $\mathrm{CO}_{2}$ laser has been demonstrated. This processing method seems to be an effective one for expanding the application of ceramics. Sound welds are obtained with the same mechanical resistance of that of the parent material. Changes in the microstructure and densification increase hardness of the weld bead.

\section{References}

1. Ikeda, M. Ceramic "Welding with Laser". Taikabutsu Overseas 5[3], 27 - 33 (1985).

2. Rice, R.W. "Welding of Ceramics". NRL Report No. 7085, Naval Research Laboratory, Washington, DC (july 6, 1970).

3. Maruo, H.; Miyamoto, I.; Arata, Y. "CO2 Laser Welding of Ceramics". In Proceedings of the 1st Laser Processing Conference. Anaheim, CA, nov. 1961.

4. Iwai, S;; Watanabe, T.; Miato, I.; Okada, K.; Morikawa, H. "Decomposition of Mullite by Silica Volatilization". J. Am. Ceram. Soc. 63[1-2], 44 - 46 (1980).

5. Heiple, C.R.; Roper, J.R.; Stagner, R.T. and Aden, R.J. "Surface Active Element Effects on the Shape of GTA, Laser, and Electron Beam Welds". Weld. J. 62[3], 72s -77s (1983). 